\title{
JURIDICAL ANALYSIS OF LEGAL AID IMPLEMENTATION FOR UNDERPRIVILEGED COMMUNITIES: PROBLEMS AND CHALLENGES
}

\author{
Alycia Sandra Dinar Andhini \\ Indonesian Legal Aid Networks, Salatiga, Indonesia \\ *Email: alyciasandra23@gmail.com
}

Legal Aid is organized to help resolve legal issues faced by Legal Aid Recipients. The birth of Law No. 16 of 2011 concerning Legal Aid provides new hope for the poor to gain access to justice and equality before the law. This writing aims to determine the implementation of the provision of legal aid and the obstacles that influence it in its implementation because sometimes the implementation of Law Number 16 of 2011 concerning Legal Aid in Indonesian Courts is not optimal. This research focuses on the application of legal aid to the poor, the challenges and problems they face. The method used in this research is empirical research. This study found that in the application of legal aid in several regions in Indonesia, the main problem faced in addition to the lack of availability of accredited legal aid institutions, was also the issue of the budget provided by the state. In addition, in terms of the legal

The Indonesian Journal of International Clinical Legal Education DOI: https://doi.org/10.15294/ijicle.v3i4.48272

Submitted: Dec 12, 2020 Revised: March 13, 2021 Accepted: August 10, 2021 Available online at https://journal.unnes.ac.id/sju/index.php/iccle (c) 2021 Authors. This work is licensed under a Creative Commons AttributionShareAlike 4.0 International License (CC BY-SA 4.0). All writings published in this journal are personal views of the authors and do not represent the views of this journal and the author's affiliated institutions. 
Aylycia Sandra Dinar Andhini

culture of the community, the implementation of legal aid is not optimal due to the understanding of the community not to have anything to do with the law so that many cases that should receive legal assistance cannot be accompanied.

Keywords: Underprivileged Community; Legal Aid; Poor People

\section{INTRODUCTION}

Legal Aid includes universally accepted rights guaranteed in the International Covenant on Civil and Political Rights (ICCPR). Articles 16 and 26 of the ICCPR are the basis for all people who are entitled to legal protection and must be avoided from all forms of discrimination. Meanwhile, Article 14 Paragraph (3) of the ICCPR provides conditions related to legal assistance, namely the interests of justice and being unable to pay for an advocate. The provisions of Article 1 Paragraph (3) of the 1945 Constitution of the Republic of Indonesia (UUD NRI 1945) confirms that the State of Indonesia is a state of law.

In a state of law, the state considers and protects the human rights of everyone, including the right to legal aid. Providing legal assistance to citizens is an effort to realize and implement a legal status that recognizes, protects, and guarantees citizens' human rights before access to justice and equality. Law (Everyone is equal before the law). The protection of constitutional rights has not received sufficient attention, so the formulation of Law Number 16 concerning Legal Aid (UUBH) in 2011 became the basis for the state to guarantee citizens, especially the poor or groups, to obtain judicial assistance and equality before the law. ${ }^{1}$

1 Yusuf Saefudin, Implementasi Pemberian Bantuan Hukum Bagi Rakyat miskin Di Jawa Tengah Berdasarkan Undang-Undang Nomor 16 Tahun 2011 Tentang Bantuan Hukum, Jurnal Idea Hukum, 2015, Vol. 1, No.1, pp. 65-66. Furthermore, it is also emphasized that legal aid for the poor is very important in the context of opening access to justice. This is because the number of lawyers in Indonesia and their distribution is not evenly distributed in each region. In fact, many districts/cities do not have an adequate number of advocates. In addition to the uneven distribution, the obligation of advocates to provide pro bono legal assistance has not been fully implemented. There is no mechanism that can ensure that every advocate has carried out the pro bono obligations mandated by Law no. 18 of 2003 concerning Advocates. That is why the state exists through the provision of free legal aid. Tens of billions of legal aid funds are provided through APBN, which is channeled through Legal Aid Providers (PBH). See also Ramdhan Kasim, "The Giving Legal Aid for the Poor on A Criminal Case." Substantive Justice International Journal of Law Vol. 1 No.1, 2018, pp. 33-45; Charlyna S Purba, "Legal aid compliance for poor local community." Journal of Advanced Research 
In relation to the Unitary State of the Republic of Indonesia as a state of law, as contained in the constitution Article 1 paragraph (3) of the 1945 Constitution hereinafter abbreviated as the 1945 Constitution. As a principle of the rule of law (rechtsstaat) it contains the principles of the rule of law, equality in public, enforcement law that does not conflict with the rules specified in the legislation, and is not a state based on power (machtsstaat). ${ }^{2}$

To be able to realize the ideal concept above, especially in the context of fulfilling the equality of every citizen under Indonesian law, it will be implemented which is closely related to access to justice, especially for the poor, namely the government by forming a policy of providing legal aid. This legal aid is the moral and professional responsibility of advocates, is individual, passive, limited to a formal approach and forms of legal assistance in the form of case assistance and defense in court.

The term legal aid itself is used as a translation of two different terms, namely "legal aid" and "legal aid". The term legal aid is usually used to express the narrow meaning of legal aid, in the form of free legal services for those involved, especially for those who are less fortunate. The definition of legal aid is used by advocates who use remuneration to express the meaning of legal aid. Legal assistance to the poor is carried out within the framework of broader efforts and objectives, not just providing legal services in court. Guided by the realization of the rule of law based on democratic principles and human rights. ${ }^{3}$ Legal aid is an obligation in order to make them aware that they have the same rights as other groups and are proactive legal subjects, not just individuals and are not limited to formal legal.

In the view of the community until now access to justice is not the property or right of everyone, but belongs to the rich, this paradigm is constructed as a result of the rampant behavior of most advocates or

in Social Sciences and Humanities Vol. 2 No.6, 2017, pp. 363-370; Auliya Rochman, "Legal Aid Institutions as a State Solution for the Poor in Getting Legal Protection." Indonesian Journal of Advocacy and Legal Services Vol. 2 No.2, 2020, pp. 211-222; Muten Nuna, Dince Aisa Kodai, and Roy Marthen Moonti. "Code of Ethics and the Role of Advocates in Providing Legal Aid to the Poor." Indonesian Journal Of Advocacy And Legal Services Vol. 1 No.2 (2020, pp. 259-274; Ridwan Arifin, "Legal Services and Advocacy in the Industrial Revolution 4.0: Challenges and Problems in Indonesia." Indonesian Journal of Advocacy and Legal Services Vol. 1 No. 2, 2020), pp. 159-162; Asri Wijayanti, "Legal aid for marginal communities." Man in India Vol. 97 No.18, 2017, pp. 251-262; Ketut Sukawati Lanang Putra Perbawa, and Maheswara Perbawa Sukawati. "Legal Assistance For The Poor." Ganaya: Jurnal Ilmu Sosial dan Humaniora Vol. 3 No.1, 2020, pp.146162 .

2 Abdurrahman, Beberapa Aspek Tentang Bantuan Hukum di Indonesia, UI, Jakarta, 1980, pp.1-2.

3 Abdurrahman, Aspek Aspek Bantuan Hukum di Indonesia, Cendana Press, Yogyakarta, 1983, pp. 34-35. 
lawyers who tend to want to help clients if their services are paid for. Citizens' access to justice is certainly related to Human Rights (HAM). In Indonesia, which adheres to the Pancasila ideology, the regulation of human rights has been regulated in Law number 39 of 1999 concerning Human Rights. ${ }^{4}$ The rights regulated and protected by Law Number 39 of 1999 concerning Human Rights, include the right to obtain justice and the right to obtain legal assistance. In this case, the judiciary is an important institution that provides the fulfillment of such access. In addition to the judiciary, the police institution also plays an important role as a means of accessing the fulfillment of access to legal justice without exception of access to the right to obtain legal assistance.

The issue of legal aid in Indonesia is one of the problems that is still quite concerning and has not been satisfactorily resolved. There are still many justice seekers who are economically incapable and marginalized communities cannot enjoy their right to obtain free legal aid. ${ }^{5}$ As mentioned above, in relation to free legal aid, which is a policy established by the government, at the normative level, it can be seen in Law Number 48 of 2009 concerning Judicial Power.

The actualization and further concretization of Law Number 16 concerning Legal Aid in 2011 has enabled the poor/poor to obtain free legal aid to make it more real and concrete, although many parties are pessimistic about the effectiveness of the promulgation of this law. Justice still needs to be given to citizens who are economically disadvantaged in order to provide the best legal assistance to people seeking justice, especially the poor and marginalized. Ensuring that everyone gets equal treatment before the law is an embodiment of the principle of equal legal protection and the principle of equality before the law guaranteed by the 1945 Constitution. This is stated in the promulgation of the latest regulation, namely Law Number 16 concerning the Legal Stone of the Year 2011. namely Law Number 16 of 2011 concerning Legal Rock.

The interesting thing since the issuance of Law no. 16 of 2011 concerning Legal Aid is that legal aid providers will receive legal aid services directly from the government and other legitimate sources, this provision is contained in the implementing regulations of Law No. 16 of 2011 concerning legal aid, namely Government Regulation No. 42 of 2013 concerning Terms and Procedures for Legal Aid and Distribution of Legal Aid. ${ }^{6}$ The state recognizes the existence of economic, social,

4 Article 1 number 1 of Law Number 39 of 1999 concerning Human Rights.

5 Bq. Ishariaty Wika Utary, Bantuan Hukum Secara Cuma-Cuma Bagi Tersangka/Terdakwa Yang Tidak Mampu, Jurnal Ius Utopia Hukum Kesejahteraan, 2014, Vol. 2 No. 1, pp. 112-113. See also Ridwan Arifin, "Legal Reform Discourse in Indonesia and Global Context: How Does the Law Respond to Crime." Journal of Law and Legal Reform Vol. 1 No.2, 2020, pp. 193-196.

6 Article 18 PP No. 42 of 2013. 
cultural, civil and political rights for the poor, so constitutionally the poor have the right to be represented and defended both inside and outside the court (access to legal counsel). Legal aid for the poor is contained in Article 34 paragraph (1) of the 1945 Constitution. So legal aid is the right of the poor that can be obtained without paying (pro bono publico) as an elaboration of equal rights before the law. Article 34 paragraph (2) and paragraph (4) of the 1945 Constitution that the state develops a social security system for all people and empowers the weak and underprivileged in accordance with human dignity as regulated in the Law on Legal Aid. ${ }^{7}$

\section{THE CONCEPT OF LEGAL ASSISTANCE: BETWEEN PRACTICE AND THEORY IN INDONESIA}

According to data from the Central Statistics Agency, the number of poor people in Indonesia in March 2009 was 37.17 million (16.58 percent). The statistical data for the poor above proves that the presence of legal aid organizations as institutions that specifically provide legal aid services for the poor is very important, so that the poor have proper access to justice. In addition, the poor who are frustrated and dissatisfied with not getting a defense from legal aid organizations will be easily trapped in a social upheaval, including violence, riots, and law violations.

This situation is certainly not comfortable for everyone because they still see the poor around them who are still frustrated. Looking at current conditions, the poor have not been able to obtain adequate legal assistance, even though in 2003 the Law on Advocates was promulgated. This Law on Advocates does recognize legal aid as an advocate's obligation, but does not elaborate further on what is meant by legal aid and how to obtain it.

So far, there has been confusion in the concept of legal aid in the form of advocate's offices claiming to be legal aid institutions but actually practicing commercial and charging fees, which deviates from the pro bono publico concept which is actually an advocate's obligation. In addition to the lawyer's office claiming to be a legal aid organization, there are also legal aid organizations that practice commercially by charging fees for providing services to their clients and not giving them to the poor on a pro bono publico basis.

The chaos in the provision of legal aid that has occurred so far is due to the absence of a clear concept of legal aid. To overcome this

\footnotetext{
7 Iwan Wahyu Pujiarto, Pelaksanaan Pemberi Bantuan Hukum Dikaitkan Dengan Undang-Undang No. 16 Tahun 2011 tentang Bantuan Hukum, USU Law Journal, 2015, Vol.3.No.2 .pp. 87-88.
} 


\section{Aylycia Sandra Dinar Andhini}

confusion, it is necessary to establish a legal aid law that clearly, explicitly, and in detail the functions of legal aid, legal aid organizations, procedures for obtaining legal aid, who provides, who is entitled to legal aid, and the state's obligation to provide legal aid funds as a constitutional responsibility. ${ }^{8}$ The existence of the legal aid law is used to manipulate the community so that the poor know their rights and know how to obtain legal aid. Meanwhile, the knowledge of the poor about their rights, especially their human rights, will only be obtained if there is a massive dissemination and counseling about their rights which is a national movement funded by the state and society. In addition, legal aid organizations must provide efforts to empower the community such as legal counseling, legal consultation, conflict control with real defense in court practice, and participating in legal development and reform and law formation, one of which is by provoking stricter jurisprudence, precise, and clear.

Prior to the reform era, the concept of legal aid was emphasized in the context of the struggle of the poor against oppressive government actions. This can be seen from several cases handled by YLBHI such as the cases of Kedung Ombo, Marsinah, Tanjung Priok, and Talangsari. However, in the reform era government that respects human rights and democracy more, the legal aid movement must change its paradigm from the concept of legal aid that places legal aid organizations at odds with the government to place the state as a partner in legal aid organizations in the context of poverty alleviation programs. Legal aid for the poor cannot be given partially and sporadically but must be given massively and invites the state c.q. government and all elements of society to introduce and encourage legal aid to the poor, both in cities and villages. Responsive legal aid provides legal assistance to the poor in all areas of law and all types of human rights free of charge by inviting the participation of the community and government as partners. This government participation can be realized by incorporating legal aid programs into poverty alleviation programs through the establishment of a legal aid law, and the provision of legal aid funds in the APBN which is regulated in the legal aid law.

In addition, in terms of providing legal aid, although the defense is carried out for all areas of law and all types of human rights, there is natural selection in everyday practice, and the organization of legal aid defense is carried out according to the professional field of each person, as in law. civil, criminal law, legal aid organizations that provide legal assistance in national administrative law or other areas of law. ${ }^{9}$ Legal aid institutions may not refuse to provide legal assistance in certain legal fields, if they do not have professional knowledge in the legal field they

8 Fransiska Novita Eleanora, Bantuan Hukum Dan Perlindungan Hak Asasi Manusia Bagi Tersangka, Lex Jurnalica Volume 9 Nomor 3, Desember 2012, pp. 147-148

$9 \quad$ Ibid., pp. 148-150. 
can entrust other legal aid agencies to handle cases or cooperate with other legal aid agencies.

Likewise, if there is a violation of human rights, legal aid organizations are required to defend without distinguishing the type of human rights being violated. This is due to the characteristics of human rights themselves which are non derogable or inalienable. As political rights are not more important than economic rights, because in the concept of human rights, if one human right is ignored, all human rights as a whole are ignored. In defending the rights of the poor, it should not be distinguished whether the collective rights or individual rights of the poor are violated, because both rights are equally important. However, operationally it is possible for a legal aid organization to focus its services on a particular area because of its capacity.

If there are legal aid organizations in certain areas of law and human rights, it is because of their capabilities and priorities, not local needs. For example, legal aid agencies in Central Java will prioritize the defense of workers in Central Java, they are not protected in the form of inhumane treatment and inadequate working conditions in terms of labor law and human rights violations. Java tends to put them first. Defenses in the field of land law, especially in areas where customary land law and the right to property protection violate human rights.

It is hoped that the concept of responsive legal aid can expand the reach of providing legal aid for the poor by making it a national movement so that the poor know and can demand their rights. In carrying out the national legal aid movement initiated by the legal aid federation, it is necessary to include an education and enlightenment program on what legal aid is, why legal aid is available, for whom legal aid is provided, and how to obtain legal aid. Without a massive legal aid program, it will not reach its target.

The legal aid program, which is implemented by involving the participation of the government and the community, is expected to become a national movement. This massive empowerment of the poor is expected to achieve the target so that the poor know their rights, and are expected to raise their dignity and social-economic position. Therefore, the current legal aid paradigm must adapt or change the steering wheel to suit the current situation and conditions. In turn, justice will apply to all people regardless of origin and background.

\section{DUTIES AND AUTHORITIES OF LEGAL ASSISTANCE INSTITUTIONS}

Law No. 16 of 2011 concerning Legal Aid as a legal umbrella regulates further the role of parties/institutions in providing legal aid. Relevant 


\section{Aylycia Sandra Dinar Andhini}

parties/institutions in probono legal aid whose roles are regulated in Law no. 16 of 2011 concerning Legal Aid are as follows:

a. Ministry of Law and Human Rights.

b. Legal aid.

c. Advocate Professional Organization.

d. Legal Aid Recipients.

Regarding the duties and authorities of the Ministry of Law and Human Rights in Law no. 16 of 2011 concerning Legal Aid is regulated in Article 1, Article 6, Article 7, Article 10, and Article 17. The department which is mandated to provide legal aid is the Minister of Law and Human Rights and Human Rights. In relation to the implementation of legal aid, the Law on Legal Aid as regulated in Article 6 paragraph (3) assigns the Minister to:

a. Develop and establish policies for legal aid providers.

b. Develop and establish legal aid standards based on the principle of providing legal aid.

c. Prepare a legal aid budget plan.

d. Manage the legal aid budget in an effective, efficient, transparent and accountable manner.

e. Prepare and submit reports on the implementation of legal assistance to the House of Representatives at the end of each fiscal year.

In addition to his duties, the minister also has several powers, according to Article 7 of the Law on Legal Aid, the minister has two powers, namely supervising and guaranteeing the implementation of legal aid and providing legal aid in accordance with his/her authority. with the provisions of the Law on Legal Aid. The principles and objectives regulated in this law are to verify and ratify legal aid institutions or community organizations to meet the qualifications of legal aid providers. ${ }^{10}$ The following are regulations regarding the role of the Ministry of Law and Human Rights as the provider of legal aid. Article 16 of 2011 concerning Legal Aid Article 1, Article 6, Article 7, Article 10, Article 17: ${ }^{11}$

Article 1. In this Law what is meant by paragraphs 4 and 5:

a. Minister is the minister who carries out government affairs in the field of law and human rights.

b. Legal Aid Standards are guidelines for the implementation of Aid provision set by the Minister.

Article 6:

1. Legal Aid is organized to assist in solving legal problems faced by Legal Aid Recipients.

10 Akhdiari Harpa, Pemberian Bantuan Hukum Bagi Masyarkat Miskin Dalam Mewujudkan Akses Keadilan Terhadap Masyarakat Miskin, Tadulako Master Law Journal, Vol 3 Issue 2, June 2019, pp. 113 - 124

11 Law No. 16 of 2011 concerning Legal Aid 
2. Provision of Legal Aid to Legal Aid Recipients shall be administered by the Minister and carried out by Legal Aid Providers based on this Law.

3. The Minister as referred to in paragraph (2) shall be in charge of:

a. Develop and establish policies for the implementation of Legal Aid.

b. Develop and establish Legal Aid Standards based on the principles of providing Legal Aid.

c. Prepare a legal aid budget plan.

d. Manage the Legal Aid budget in an effective, efficient, transparent and accountable manner.

e. Prepare and submit reports on the implementation of Legal Aid to the House of Representatives at the end of each fiscal year.

Article 7

1. To carry out the tasks as referred to in Article 6 paragraph (3), the Minister is authorized to:

a. Supervise and ensure that the implementation of Legal Aid and the provision of Legal Aid is carried out in accordance with the principles and objectives stipulated in this Law.

b. Verify and accredit legal aid institutions or community organizations to fulfill eligibility as Legal Aid Providers based on this Law.

2. To carry out the verification and accreditation as referred to in paragraph (1) letter $b$, the Minister forms a committee whose elements consist of:

a. The ministry that carries out government affairs in the fields of law and human rights.

b. Academics.

c. Public figure.

d. Institutions or organizations that provide Legal Aid services.

3. Verification and accreditation as referred to in paragraph (1) letter b is carried out every 3 (three) years.

4. Further provisions regarding procedures for verification and accreditation as referred to in paragraph (1) letter $b$ shall be regulated by a Ministerial Regulation.

Based on the above discussion, one of the duties of the Minister of Law and Human Rights as a legal aid provider is regulated in Article 6 of Law Number 16 concerning Legal Aid of 2011. "Policy of the Ministry of Law and Human Rights (PerMenKumham) Number 63 of 2016 concerning Amendments on PerMenKumHam Number 10 of 2015 concerning the Implementation of Government Regulation Number 42 of 2013 concerning Provisions and Procedures for Providing Legal Aid and Distribution of Legal Aid Funds. There has been a normative (antinomical) conflict with the Minister of Law and Human Rights regarding "free legal aid providers". 


\section{Aylycia Sandra Dinar Andhini}

Contrary to PerMenKumHam Number 1 of 2018 concerning the provision of legal aid by paralegals, there is a higher regulation on legal aid. Advocates and Government Regulations (PP) concerning the Implementation of the Legal Aid Law Number 18 of 2003. Number 16 of 2011 is PP Number 4242 of 2013 concerning Provisions and Procedures for Providing Legal Aid and Distribution of Legal Aid Funds, as explained in Permenkumham Number 1 of 2018 concerning Provision of Paralegal Legal Aid Chapter 3 Paralegal Empowerment The contents of Article 11 reads "A paralegal can provide legal assistance for litigation and non-legal assistance". After registering with a legal aid provider and obtaining a paralegal training certificate, a lawsuit is filed. ${ }^{12}$

Law on Advocates, PP No. 42 of 2013 and Permenkumham No. 63 of 2016, explicitly state that the implementer of the litigation legal aid provider is an "advocate". The following is an explanation of the article:

a) Law no. 18 of 2008 concerning Advocates is regulated in the General Provisions of Article 1 paragraph (1) and Paragraph (9). Paragraph (1). An advocate is a person who has the profession of providing legal services both inside and outside the court who meets the requirements based on the provisions of the law. Verse (9). Legal Aid is a legal service provided by Advocates free of charge to clients who cannot afford it.

b) Government Regulation (PP) No. 42 of 2013 concerning Terms and Procedures for Providing Legal Aid and Distribution of Legal Aid Funds. Legal aid providers are regulated in CHAPTER 2 Terms and Procedures for Providing Legal Aid In Article 13 Paragraph (1), "The provision of legal aid in litigation is carried out by Advocates with the status of administrators of legal aid providers and/or Advocates recruited by legal aid providers.

c) Regulation of the Minister of Law and Human Rights (PerMenKumHam) No. 63 of 2016 concerning Amendments to PerMenKumHam No. 10 of 2015 concerning the implementation of Government Regulation No. 42 of 2013 concerning the requirements and procedures for the provision of legal aid and distribution of legal aid funds. Legal aid providers in litigation are regulated in Article 27 Paragraph (1). "The provision of legal aid in litigation is carried out by advocates who have the status as administrators of legal aid providers and/or advocates who are registered with legal aid providers.

12 See Aprila Niravita, "The Role of Law Students on Strengthening Village Human Resources in the Era of the Industrial Revolution 4.0." Indonesian Journal of Advocacy and Legal Services Vol 1 No.1, 2019, pp. 1-4; Saru Arifin, "Commitment of Local Government in Providing Legal Aid for the Poor Society." Jurnal Dinamika Hukum Vol. 16 No.1, 2016, pp. 8-16. 
In connection with the conflict of norms between one regulation and another, the role of legal science as the principles of conflict resolution are: ${ }^{13}$

a. The principle of lex posterior (lex posterior derogat legi priori), which means that the law then beats the previous one.

b. The principle of lex specialis (lex specialis derogat legi priori), which means that special laws override general ones.

c. The principle of lex superior (lex superior derogate legi inferiori), means that the higher laws beat the lower ones.

Norm conflict between Pemenkumham No. 1 of 2018 with other related regulations regarding legal aid, namely the Law on Advocates, Government Regulations (PP), and the Permenkumham itself, when examining the principles of conflict resolution as described above, the author is of the opinion that when referring to the principle of lex superior (The higher laws beat the lower ones).

\section{IMPLEMENTATION OF FREE LEGAL ASSISTANCE FOR POOR COMMUNITIES}

In the general provisions of Chapter I Article 1 of Law No. 16 of 2011 are:

1. Legal Aid is legal services provided by Legal Aid Providers free of charge to Legal Aid Recipients.

2. Legal Aid recipients are poor people or groups of people. Legal Aid Provider is a legal aid institution or community organization that provides Legal Aid services under this Law.

3. Minister is the minister who carries out government affairs in the field of law and human rights.

4. Legal Aid Standards are guidelines for the implementation of the provision of Legal Aid determined by the Minister.

5. Advocate's Code of Ethics is the code of ethics set by the advocate's professional organization that applies to Advocates.

Article 1 Paragraph (2) UUBH Implementing the Provision of Legal Aid is a Legal Aid Institution or Community Organization hereinafter abbreviated as LBH and Orkemas. Article 8 of the Legal Aid Law No. 16 of 2011:

1. Implementation of Legal Aid is carried out by legal aid providers who have met the requirements under this law.

2. The requirements for providing legal aid as referred to in paragraph (1) include:

13 Philipus Madiri Hajon. Pengkajian Hukum Dogmatik (Normatif).Yuridika. No.6 Tahun IX.November-Desember 1994 


\section{Aylycia Sandra Dinar Andhini}
a. Incorporated
b. Accredited under this law.

3. Have a permanent office or secretariat. Have a legal aid program.

The same definition is also given by Law Number 18 of 2003 concerning Advocates, in Article 1 point 9 it is explained that "legal assistance is legal services provided by advocates free of charge to clients who cannot afford it." Based on the definitions of the two laws, it can be concluded that legal aid is legal service that is provided free of charge, the provisions of Article 1 of the Advocate Law provides the understanding "Advocacy is a person who has the profession of providing legal services both inside and outside the court who fulfills the requirements based on the provisions of the law. ${ }^{14}$

Government Regulation (PP) No. 42 of 2013 concerning Terms and Procedures for Providing Legal Aid and Distribution of Legal Aid Funds. As a guideline for implementing Law NO 16 of 2011 on Legal Aid in Article 4, legal aid providers must meet the following requirements:
a. Incorporated.
b. Accredited.
c. Have a permanent office or secretariat.
d. Own the Manager.
e. Have a Legal Aid Program. ${ }^{15}$

The implementers of providing Free Legal Aid, which are regulated in special arrangements, such as Laws, Government Regulations, and Ministerial Regulations, as explained above are as follows:

1. Constitution

a. Law No. 18 of 2003 concerning Advocates.

b. Law No. 16 of 2011 concerning Legal Aid.

2. Government Regulation (PP)

a. PP No. 42 of 2013 concerning Procedures for Providing Legal Aid and Distribution of Legal Aid Funds.

b. PP No. 83 of 2008 concerning Requirements and Procedures for Providing Free Legal Aid

3. Regulation of the Minister of Law and Human Rights (PerMenKumHam)

a. PerMenKumHam No. 63 of 2016 concerning Amendments to Permenkumham No. 10 of 2015 concerning Implementing Regulations of Government Regulation No. 42 of 2013

14 Asfinawati, Prolog: Bantuan Hukum Cuma-Cuma dan Komersialisasi, dalam Lembaga Bantuan Hukum Jakarta, Bantuan Hukum Akses Masyarakat Miskin dan Marjinal terhadap Keadilan, LBH : Jakarta. 2001, p. 4

15 Government Regulation No. 42 of 2013 concerning Terms and Procedures for Providing Legal Aid and Distribution of Legal Aid Funds 
concerning Terms and Procedures for Providing Legal Aid and Distribution of Legal Aid Funds.

b. PerMenKumHam No. 1 of 2018 concerning Paralegals in Providing Legal Aid.

Laws, Government Regulations, and Regulations of the Minister of Law and Human Rights which regulate the provision of free legal aid. Litigation can only be carried out by Advocates registered with $\mathrm{LBH} / \mathrm{OBH}$ who are verified and accredited by the Ministry of Law and Human Rights as the implementing legal aid agency.

\section{OBSTACLES FOR IMPLEMENTATION OF LEGAL ASSISTANCE SERVICES FOR POOR COMMUNITIES}

Legal aid is the right of a person who cannot afford it, which has been regulated in detail in the legislation, but to obtain legal assistance from advocates in enforcing the idea of legal aid, there are several inhibiting factors that will become obstacles.

According to Soerjono Soekanto, the factors that hinder law enforcement, especially in terms of legal aid are as follows: ${ }^{16}$

a. The legal factor itself is a law.

b. Law enforcement factors, namely the parties that form and apply the law.

c. Factors of facilities or facilities that support law enforcement.

d. Community factors, namely the environment in which the law applies or is applied;

e. Cultural factors, namely as a result of work, creativity and taste based on human initiative in social life.

Moch Ali said there are not many obstacles to the court's appointment of a defense, because court-appointed defenders are always ready and willing to accompany the accused during the trial, in that case only court-appointed defenders can be unwilling, but in general, he is appointed by the court. Defenders are always ready. He said the lack of legal aid funds provided by the government through the Ministry of Law and Human Rights hampered the implementation of legal aid for the poor. The funds given to the court are still not sufficient to meet the financial needs of the lawyers, so they are willing to provide free legal aid to the poor through Posbakum at the district court level. According to Herwanto Semenguk, the factors that hinder the provision of legal aid to defendants who cannot afford are:

a. Community Factor

16 Soerjono Soekanto, Faktor-Faktor Yang Mempengaruhi Penegakan Hukum, Jakarta: PT Raja Grafindo Persada, pp. 3-4 


\section{Aylycia Sandra Dinar Andhini}

This meaning is an indicator of the effectiveness of the law, which can be seen from the public's understanding of the law, which in this case is legal aid. Generally, people who are financially underprivileged do not really understand the free legal aid provided by advocates. Some people cannot afford not to use the services of an advocate, because in their opinion, if they use the services of an advocate, they will spend a lot of money. bigger. As a result, not all poor people undergoing criminal and civil proceedings have access to legal aid.

b. Cultural Factor

This means that the public has the opinion that if they want to be accompanied by an advocate, they must provide a lot of funds, then they have to complete so many administrative arrangements so that most people who can't afford it in the end don't want to. to be advocated Accompanied by the person. This has become a paradigm inherent in community legal aid, and has become a culture that grows in the community, so that in the judicial process they still find cases of poor people without defenders. Even though this kind of assistance is legally free or free, it is true, and it has also been regulated in the laws and regulations.

According to Maroni, the provision of legal assistance to defendants who cannot afford will be influenced by various factors, namely: ${ }^{17}$

1) Law Enforcement Factor

The parties who apply the law for an advocate who refuses to provide free legal aid in general to do so. In accordance with PP No. 83 concerning Requirements and Procedures for Providing Free Legal Aid, it has been explained that for advocates who are not willing to provide legal assistance, they will be given sanctions in the form of:

a) Verbal warning.

b) written warning.

c) Temporary dismissal from his profession for 3 (three) to 12 (twelve) consecutive months.

d) Permanent dismissal from his profession.

In reality, strict sanctions cannot be applied to advocates who refuse to provide free legal aid, so the law enforcement process for advocates who refuse to provide free legal aid to underprivileged communities, both those in the courts and those in the courts. in the Legal Aid Institute (LBH) has not been able to run well.

2) Lack of Facilities or Infrastructure

17 Andry Rahman Arif, Pelaksanaan Pemberian Bantuan Hukum Terhadap Terdakwa Yang Tidak Mampu Dalam Perkara Pidana Di Kota Bandar Lampung, Fiat Justisia Jurnal Ilmu Hukum Volume 9 No. 1, Januari-Maret 2015, pp. 109-110. 
Due to the lack of facilities and infrastructure to travel to these places, the courts and LBH still do not socialize the provision of free legal aid to the poor, especially in remote areas. This causes most people, especially those who cannot afford it, to lack understanding of the provision of free legal aid. The limited funds provided by the government are one of the causes of the lack of socialization of free legal aid. Provide legal assistance to communities in remote areas.

There are also several things that become obstacles in the context of the effectiveness of providing legal aid services that can be carried out directly by the Supreme Court and the judicial institutions below it, namely, the lack of socialization of Law no. 16 of 2011 concerning Legal Aid, so that it has an impact on:

a. Lack of Public Knowledge of Legal Services

In this case, public knowledge refers to institutions that are not known to have the authority to provide legal aid services to the poor other than the courts. The public only knows that so far only the judiciary has provided this access, namely through the POSBAKUM service provided by the judiciary. Therefore, in terms of quantity, people tend to submit applications to the prosecutor's office, on the one hand the prosecutor's office itself is constrained by the availability of budget funds.

b. Lack of Knowledge of Institutions Outside the Court

In this case, it refers to a lack of understanding of the mechanisms and administrative requirements of legal aid institutions, legal aid organizations, and others to become legal aid institutions or providers that can provide legal aid services, called $(\mathrm{PBH})$ to the community. can't do. This case involves legal aid agencies, legal aid agencies and other mechanisms that can provide legal aid services and strict administrative requirements before they can be called $\mathrm{PBH}$, and legal aid organizations must go through verification procedures and be executed by the government. If the OBH succeeds in meeting all the requirements required in the verification process, the government will certify that the $\mathrm{OBH}$ has passed the verification and determine the approved value. An accredited $\mathrm{OBH}$ can be considered a PBH and can provide legal aid services in accordance with the Legal Aid Act. In addition, many PBH institutions that have provided legal aid services admit that they are reluctant to make reimbursements to BPHN, considering the quite complicated requirements that must be met.

c. Lack of Coordination Between Legal Aid Agencies and Courts

The courts are not aware of legal aid institutions that have passed the test and have never established an official legal aid agency. coordination or submission has been approved and verified and provides free legal aid services to the poor because the government 


\section{Aylycia Sandra Dinar Andhini}

has provided the budget through BPHN. The court only knew about Posbakum who had been in court. ${ }^{18}$

\section{CONCLUSION}

This study concludes that the obstacles faced in the implementation of Law no. 16 of 2011 concerning Legal Aid for the poor, among others, covering juridical constraints, namely the ambiguity of legal norms and non-juridical constraints, including lack of socialization, limited budget for legal aid for the poor. As a legal aid provider, who has the task of formulating and determining legal aid policies, the government, in this case (minister) of Law and Human Rights, in making policies on legal aid to pay more attention to legal norms and principles so that there are no conflicts of norms between similar regulations and/or higher rules. There needs to be a role and synergy between the government both at the central and regional levels with advocates, $\mathrm{LBH} / \mathrm{OBH}$ in promoting legal aid programs in order to achieve or grow new accredited and verified $\mathrm{LBH} / \mathrm{OBH}$, as a condition as the implementation of providing free legal aid for the poor. the implementation of the provision of legal aid for the poor to be further improved by enlarging the budget post and collaborating with professional institutions or organizations and all courts or the Mataram Legal and Human Rights Regional Office to be more intensive and proactive in socializing Law no. 16 of 2011 to related parties, especially the poor who are in conflict with the law.

\section{REFERENCES}

Abdurrahman, A. (1980). Beberapa Aspek Tentang Bantuan Hukum di Indonesia. Jakarta: UI Press.

Abdurrahman, A. (1983). Aspek Aspek Bantuan Hukum di Indonesia. Yogyakarta: Cendana Press.

Arif, A. R. (2015). Pelaksanaan Pemberian Bantuan Hukum Terhadap Terdakwa Yang Tidak Mampu Dalam Perkara Pidana Di Kota Bandar Lampung. Fiat Justisia Jurnal Ilmu Hukum, 9(1).

Arifin, R. (2020). Legal Reform Discourse in Indonesia and Global Context: How Does The Law Respond to Crime. Journal of Law and Legal Reform, 1(2), 193-196.

18 Lalu Muhammad Taufik, Implementasi Bantuan Hukum Bagi Masyarakat Miskin (Studi Kasus Di Pengadilan Agama Mataram, Jurnal IUS, Vol V,Nomor 3, Desember 2017, hlm. 463 - 480 
Arifin, R. (2020). Legal Services and Advocacy in the Industrial Revolution 4.0: Challenges and Problems in Indonesia. Indonesian Journal of Advocacy and Legal Services, 1(2), 159-162.

Arifin, S. (2016). Commitment of Local Government in Providing Legal Aid for the Poor Society. Jurnal Dinamika Hukum, 16(1), 8-16.

Asfinawati, A. (2001). "Prolog: Bantuan Hukum Cuma-Cuma dan Komersialisasi", In Lembaga Bantuan Hukum Jakarta, Bantuan Hukum Akses Masyarakat Miskin dan Marjinal terhadap Keadilan. Jakarta: LBH

Eleanora, F. N. (2012). Bantuan Hukum Dan Perlindungan Hak Asasi Manusia Bagi Tersangka. Lex Jurnalica, 9(3).

Harpa, A. (2019). Analisis Yuridis Pemberian Bantuan Hukum Bagi Masyarkat Miskin dalam Mewujudkan Akses Keadilan Terhadap Masyarakat Miskin. Tadulako Master Law Journal, 3(2), 113-124.

Kasim, R. (2018). The Giving Legal Aid for the Poor on A Criminal Case. Substantive Justice International Journal of Law, 1(1), 3345.

Niravita, A. (2019). The Role of Law Students on Strengthening Village Human Resources in the Era of the Industrial Revolution 4.0. Indonesian Journal of Advocacy and Legal Services, 1(1), 1-4.

Nuna, M., Kodai, D. A., \& Moonti, R. M. (2020). Code of Ethics and the Role of Advocates in Providing Legal Aid to The Poor. Indonesian Journal of Advocacy and Legal Services, 1(2), 259-274.

Perbawa, K. S. L. P., \& Sukawati, M. P. (2020). Legal Assistance for the Poor. Ganaya: Jurnal Ilmu Sosial dan Humaniora, 3(1), 146-162.

Pujiarto, I. W. (2015). Pelaksanaan Pemberi Bantuan Hukum Dikaitkan dengan Undang-Undang No. 16 tahun 2011 tentang Bantuan Hukum. USU Law Journal, 3(2).

Purba, C. S. (2017). Legal aid compliance for poor local community. Journal of Advanced Research in Social Sciences and Humanities, 2(6), 363-370.

Republic of Indonesia. (1999). Law No. 39 of 1999 on Human Rights (Undang-Undang Nomor 39 Tahun 1999 Tentang Hak Asasi Manusia).

Republic of Indonesia. (2011). Law No. 16 of 2011 concerning Legal Aid (Undang Undang No. 16 Tahun 2011 tentang Bantuan Hukum).

Republic of Indonesia. (2013). Government Regulation No. 42 of 2013 concerning Terms and Procedures for Providing Legal Aid and Distribution of Legal Aid Funds (Peraturan Pemerintah No. 42 Tahun 2013 Tentang Syarat Dan Tata Cara Pemberian Bantuan Hukum Dan Penyaluran Dana Bantuan Hukum).

Rochman, A. (2020). Legal Aid Institutions as a State Solution for the Poor in Getting Legal Protection. Indonesian Journal of Advocacy and Legal Services, 2(2), 211-222. 


\section{Aylycia Sandra Dinar Andhini}

Saefudin, Y. (2015). Implementasi Pemberian Bantuan Hukum Bagi Rakyat miskin Di Jawa Tengah Berdasarkan Undang-Undang Nomor 16 Tahun 2011 Tentang Bantuan Hukum. Jurnal Idea Hukum, 1(1).

Soekanto, S. (2002). Faktor-Faktor Yang Mempengaruhi Penegakan Hukum. Jakarta: PT Raja Grafindo Persada.

Taufik, L. M. (2017). Implementasi Bantuan Hukum Bagi Masyarakat Miskin (Studi Kasus di Pengadilan Agama Mataram). Jurnal IUS Kajian Hukum dan Keadilan, 5(3), 463-480.

Utary, B. I. W. (2014). Bantuan Hukum Secara Cuma-Cuma Bagi Tersangka/Terdakwa Yang Tidak Mampu. Jurnal Ius Utopia Hukum - Kesejahteraan, 2(1).

Wijayanti, A. (2017). Legal aid for marginal communities. Man in India, 97(18), 251-262.

\section{Conflicting Interest Statement}

All authors declared that there is no potential conflict of interest on publishing this article.

\section{Funding}

None

\section{Publishing Ethical and Originality Statement}

All authors declared that this work is original and has never been published in any form and in any media, nor is it under consideration for publication in any journal, and all sources cited in this work refer to the basic standards of scientific citation.

Cite this article as:

Andhini, A. S. D. (2021). Juridical Analysis of Legal Aid Implementation for Underprivileged Communities: Problems and Challenges. The Indonesian Journal of International Clinical Legal Education, 3(4), 481-498. https://doi.org/10.15294/ijicle.v3i4.48272 